\title{
Prenatal Repair of Myelomeningocele
}

Jose Roberto Tude Melo*, Paulo Roberto Tavares Gomes Filho, Caio Nogueira Lessa, Kleber Pimentel Santos, Gilvan da Silva Figueiredo and Vera Lucia Fernandes de Azevedo

Group of Fetal Surgery, Maternity Climério de Oliveira - Federal University of Bahia, Brazil

*Corresponding author: Jose Roberto Tude Melo, MD, PhD, Pediatric Neurosurgery Hospital Martagão Gesteira (Children Hospital) Hospital Sao Rafael Federal University of Bahia, Brazil Neurocirurgia Pediatricam RM 14147, Brazil, Tel: (00-55-71) 21092611/99791806; E-mail: robertotude@gmail.com

Rec date: Nov 01, 2014, Acc date: Nov 03, 2014, Pub date: Nov 05, 2014

Copyright: $\odot 2014$ Melo JRT, et al. This is an open-access article distributed under the terms of the Creative Commons Attribution License, which permits unrestricted use, distribution, and reproduction in any medium, provided the original author and source are credited.

\section{Description}

The myelomeningocele (MMC) is a failure in embryo development during the fourth week of gestation, being the most common form of spinal dysraphism characterized by a protrusion of the meninges, roots and spinal cord by a bony midline defect $[1,2]$. The MMC treatment is surgical and should be implemented as soon as possible in order to reduce the exposure of the neural tissue and consequently the risk of infections and worsening of neurological deficits $[3,4]$. The incidence of hydrocephalus is higher in cases of neonates whose surgical repair of MMC is done after the child's birth (postnatal repair of myelomeningocele), when compared to the group of children undergoing intrauterine surgery [4]. For children whose correction and closing of the MMC is still done during intrauterine life (known as intrauterine fetal open surgery; (Figure 1), the incidence of hydrocephalus can be reduced by $50 \%$, as well as motor deficits [4]. In Figure 1 we show the image of the first fetal neurosurgery performed in the northeast region of Brazil, with excellent result [5].

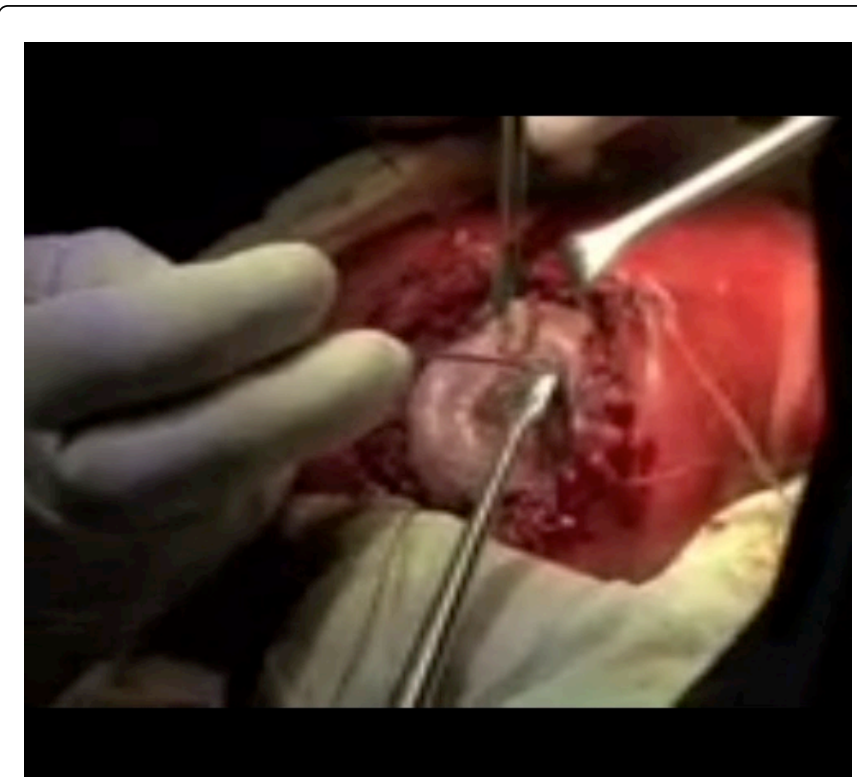

Figure 1: Intrauterine fetal open surgery.

\section{References}

1. Adzick NS, Walsh DS (2003) Myelomeningocele: prenatal diagnosis, pathophysiology and management. Semin Pediatr Surg 12: 168-174.

2. Bruner JP, Tulipan N, Paschall RL, Boehm FH, Walsh WF, et al. (1999) Fetal surgery for myelomeningocele and the incidence of shunt-dependent hydrocephalus. JAMA 282: 1819-1825.

3. Pinto FC, Matushita H, Furlan AL, Alho EJ, Goldenberg DC, et al. (2009) Surgical treatment of myelomeningocele carried out at 'time zero' immediately after birth. Pediatr Neurosurg 45: 114-118.

4. Adzick NS, Thom EA, Spong CY, Brock JW 3rd, Burrows PK, et al. (2011) A randomized trial of prenatal versus postnatal repair of myelomeningocele. N Engl J Med 364: 993-1004.

5. http://www.sbn.com.br/index/noticias/2014-09-01-primeira-cirurgia-fetaldo-estado-da-bahia. 